\title{
Pemberdayaan Masyarakat Melalui Media Sosial Sebagai Media Promosi UMKM Era New Normal di Desa Gunungsari, Kecamatan Kasreman, Kabupaten Ngawi
}

\author{
Community Empowerment through Social Media as a New Normal Era of MSME Promotion Media in Gunungsari \\ Village, Kasreman District, Ngawi Regency
}

Dimas Satria Laksmana ${ }^{1 *}$, Arief Setyawan ${ }^{2}$

Citation: Laksmana, D.S., Setyawan, A. Pemberdayaan Masyarakat Melalui Media Sosial Sebagai Media Promosi UMKM

Era New Normal di Desa Gunungsari, Kecamatan Kasreman, Kabupaten Ngawi. Buletin Pemberdayaan Masyarakat dan Desa 2021, 1(1), 20-26. https://doi.org/10.21107/bpmd.v1i1. 12016

Received: July, 2021

Accepted: August, 2021

Published: September, 2021

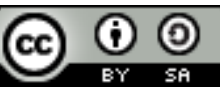

Copyright: (c) 2021 by the authors. Submitted for possible open access publication under the terms and conditions of the Creative Commons Attribution (CC BY SA) license (https://creativecommons.org/license s/by-sa/4.0/).

\author{
1 Sosiologi, Universitas Trunojoyo Madura; Jl Raya Telang, Kamal Bangkalan Kode Pos 69162; \\ 2 Pendidikan Bahasa dan Sastra Indonesia, Universitas Trunojoyo Madura; Jl Raya Telang, Kamal Bangkalan \\ Kode Pos 69162; \\ *Correspondence: dimassatrialaksmana@gmail.com;
}

\begin{abstract}
Abstrak: Hingga saat ini pandemi Covid-19 belum mereda. Berbagai kebijakan mulai dari PSBB, anjuran selalu mencuci tangan, mengguanakan masker saat keluar rumah hingga menjaga jarak dengan orang lain sudah diterapkan oleh pemerintah Indonesia. Pandemi ini menyebabkan dampak di berbagai aspek dan sektor dalam kehidupan masayarakat. Salah satunya dampak ekonomi para pelaku UMKM. Para pelaku UMKM mengeluhkan bahwa tingkat pendapatan dan komsumi masayarakat menurun sejak adanya pandemi. Para pelaku usaha tidak bisa berdiam diri mereka harus melakukan tindakan untuk keberlangsungan usahanya. Pemanfaatan media sosial untuk media pemasaran dirasa tepat untuk menghadapi masa pandemi seperti saat ini. Maka perlu adanya pemberdayaan masayarakat agar mengetahui dan dapat menggunakan media sosial sebagai media promosi. Media sosial yang sangat mudah digunakan adalah Facebook dan Instagram. Pengabdian masayarakat dengan cara memberikan sosialisasi dan pelatihan dirasa dapat membawa perbuahan pada pelaku usaha agar tetap menjalankan usahanya.
\end{abstract}

Keywords: Pemberdayaan Masyarakat, Media Sosial, Media Promosi, UMKM

Abstract: So far, the Covid-19 pandemic has not subsided. Various policies ranging from PSBB, recommendations for always washing hands, using masks when leaving the house to maintaining distance from other people have been implemented by the Indonesian government. This pandemic has had an impact on various aspects and sectors of people's lives. One of them is the economic impact of UMKM actors. UMKM actors complain that the level of income and consumption of the community has decreased since the pandemic. Business actors cannot remain silent, they must take action for the sustainability of their business. The use of social media for marketing media is considered appropriate to face the current pandemic. So it is necessary to empower the community to know and be able to use social media as a promotional medium. Social media that are very easy to use are Facebook and Instagram. Community service by providing socialization and training is felt to be able to bring fruit to business actors so that they can continue to run their business.

Keywords: Community Empowerment, Social Media, Promotional Media, UMKM

\section{PENDAHULUAN}

Sudah hampir 1 setengah tahun ini seluruh negara bagian dunia sedang mengalami kondisi yang sangat berat karena munculnya pandemi virus Covid-19. Virus ini menyerang pernafasan manusia hingga dapat menyebabkan kematian. Awal mula kemunculan virus ini di Wuhan, China pada awal bulan Maret 2020 dan mulai masuk Indonesia pada tanggal 2 Maret 2020. Sehingga menyebabkan keresahan masayarakat Indonesia .

Lalu, pemerintah Indonesia membuat berbagai kebijakan untuk menenkan angka penyebaran pandemi ini diantaranya adalah kebijakan PSBB, menjaga jarak, mencuci 
tangan, dan memakai masker jika keluar rumah. Hingga penutupan tempat umum seperti sekolah, kampus dan kantor mewajibkan karyawannya untuk bekerja dari rumah. Masyarakat juga banyak yang melaksanakan stay at home sesuai himbauan dari pemerintah yang mengakibtkan pendapatan masayarakat menurun dan tingkat konsumsi menurun (Abidin Achmad et al., 2020).

Pandemi Covid-19 memberikan dampak yang sangat besar terhadap berbagai aspek dan sektor di masayarakat salah satunya pada sektor ekonomi terutama pada kegiatan UMKM di Desa Gunungsari. Penurunan pendapatan, dan penjualan sangat di rasakan setelah adanya pandemi ini. Kian hari keadaan kian memburuk sehingga para pelaku UMKM segera mengambil langkah demi keberlangsungan usahanya salah satunya mengikuti pelatihan media promosi menggunakan media sosial (Muzdalifah, Novie, \& Zaqiyah, 2020).

Perkembangan teknologi informasi yang semakin canggih membuat para pelaku usaha memilih menggunakan media sosial sebagai media promosi. Hal ini merupakan langkah yang tepat di saat situasi seperti ini. Media sosial telah menjadi pilihan utama masyarakat dalam mencari dan menyampaikan infromasi. Media sosial juga dapat memberikan dampak kemajuab pada bisnis para pelaku usaha. Media sosial dapat digunakan dalam menyampaikan infromasi produk, membantu pemasaran, berkomunikasi dengan pembeli, mengurangi biaya dan melakukan penjualan online (Sembiring, Neta, Nashrullah, Wirawan, \& Lumombo, 2019).

Media sosial merupakan media online dimana para penggunanya dengan mudah berinterasksi, berbagi, dan menciptakan isi. Ada banyak jenis media sosial yaitu blog, wiki, jejaring sosial, forum dan dunia virtual. Bentuk yang paling umum diguanakan masayarakat adalah blog, wiki dan jejaring sosial. Media sosial telah menjadi trend dalam masayarakat karena hanya dengan jari semua dapat dicari.

10 Media Sosial yang Sering Digunakan 2020

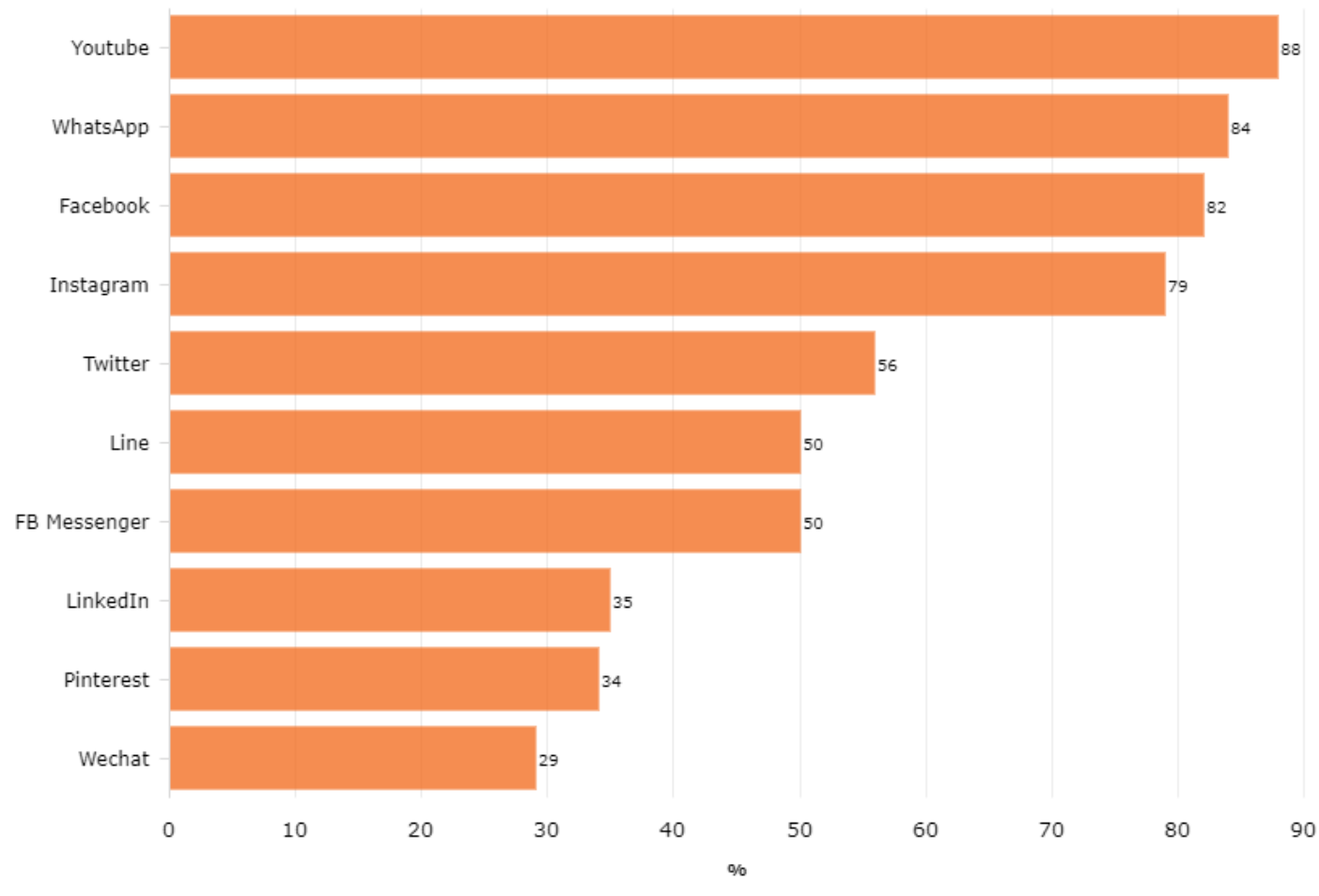

Gambar 1. Platform Media Sosial yang sering digunakan tahun 2020-2021 Sumber : (We are Social, 2020) 
Data diatas yang dipaparkan oleh We are Social (We are Social, 2020), YouTube merupaakn sebuah media online yang paling sering digunakan oleh pengguna media sosial di Indonesia dengan persentase pengguna yang mencapai 88\% dan berusia antara 16 dan 64 tahun. Diikuti oleh media sosial yang paling sering dikunjungi, termasuk WhatsApp dengan presentase seitar 84\%, Facebook degan presentase pengguna mencapai $82 \%$ serta Instagram dengan pengguna sekitar 79\%. Rata-rata waktu kunjungan orang Indonesia ke media sosial adalah 3 jam 26 menit. Sedangkan jumlah total pengguna media sosial aktif adalah sekitar 160 juta, terhitung dari 59\% total penduduk Indonesia. $99 \%$ pengguna media sosial yang menjelajahi Internet menggunakan ponsel.

Media sosial yang sedang trend saat ini memberikan peluang besar kepada pelaku usaha untuk mempromosikan produknya melalui media sosial tersebut. Dengan media sosial para pelaku usaha dapat memberikan efesiensi anggaran pemasaran, memiliki jaringan yang luas, akses mudah dan biaya murah. Selain itu dengan adanya himbauan untuk jaga jarak dan stay at home mengakibatkan para pelaku usaha berani mencoba menggunakan media sosial sebagai media promosi. Media sosial digunakan untuk alat untuk mengembangan serta mengoptimalkan usaha terutama UMKM. Keuntungan yang di dapat yaitu jaringan yang luas sehingga produk dapat di jangkuan tanpa batas wilayah dan waktu sehingga sangat efektif (Dwi Riyanto \& Noeris, 2018).

Pemberdayaan masayarakat melalui pelatihan promosi menggunakan media sosial diharpakan dapat membawa perubahan ke arah yang lebih baik. Para pelau usaha dapat mengoptimalkan dan meningkatkan pengetahuan mengenai sistem pemasaran melalui media sosial. Sebab pemasaran melalui media sosial akan memudahkan para pelau usaha dengan begitu produk mereka akan di kenal masayarak luas, pemesanan dapat dilakukan secara online, sehingga memberikan kemudahan bagi para pelaku usaha di tengah pandemi Covid-19 seperti saat ini (Permana \& Cendana, 2019b).

Era globalisasi saat ini juga dikenal dengan Era Ekonomi Baru, Era Ekonomi Digital. Penerapan teknologi informasi di sektor bisnis menandai lahirnuya Era Ekonomi Baru. Penerapan teknologi informasi yang dibutuhkan adalah pemasaran produk melalui media sosial facebook dan instagram. Hal ini dirasa lebih praktis dan lebih mudah dibangdingkan dengan pemasaran secara manual (Mansir, 2021).

Pemanfaatan media sosial banyak memberikan kemudahan dan memberikan keuntungan bagi para pelaku UMKM. Namun masih banyak pelaku UMKM belum dapat memanfaatkan media sosial sebagai tempat pemasaran usahanya. Mereka masih menggunakan cara yang tradisonal dengan memasarkan secara langsung kepada konsmuen yang sering dilakukan oleh para pelaku usaha yang sudah tua. Atas latar belakang tersebut, KKNT UTM Jawa Timur Kelompok 65, yang dilaksnakan di Desa Gunungsari, Kecamatan Kasreman, Kabupaten Ngawi menggunakan latar belakang tersebut sebagai program kerja.

\section{METODE}

Pengabdian masayarakat ini dilakukan di Desa Gunungsari, Kecamatan Kasreman, Kabupaten Ngawi dengan cara memberikan sosialisasi dan pelatihan tentang pemasaran melalui media sosial. Sosialisasi dan pelatihan ini dihadiri oleh beberapa perwakilan Ibu-ibu pelaku UMKM setempat dan juga beberapa warga Desa Gunungsari. 


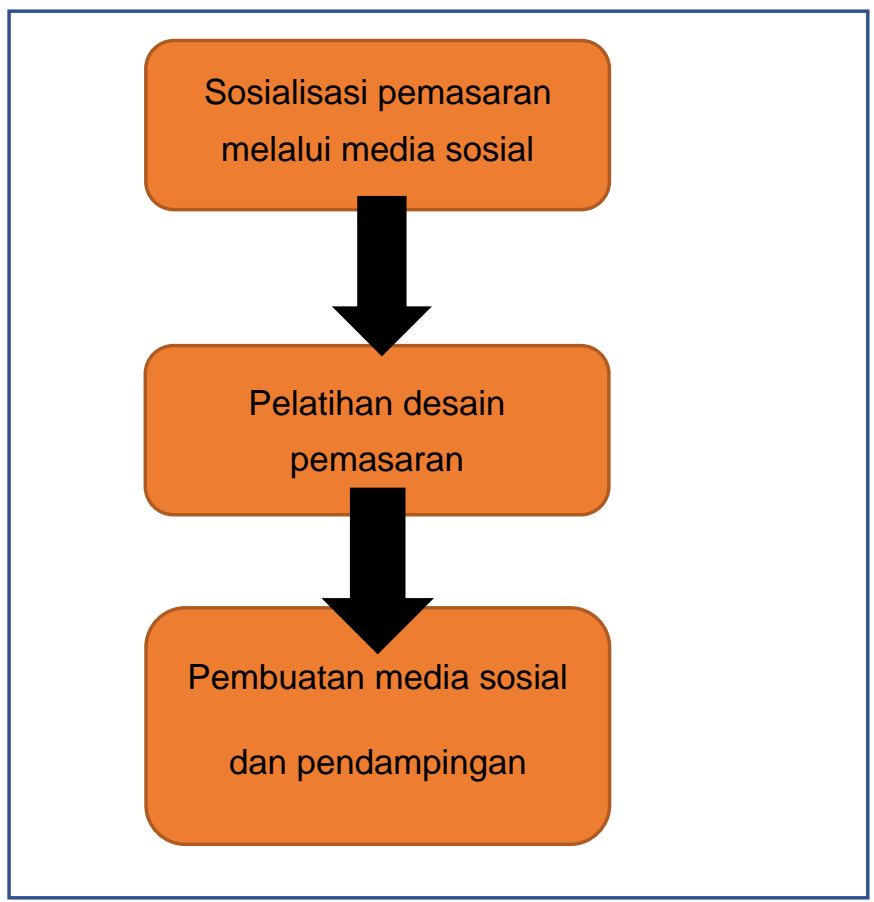

Gambar 2. Alur proses pelaksanaan Kegiatan

Kegiatan pengabdian ini memiliki 3 buah materi yaitu :

1. Sosialisasi pemasaran melalui media sosial

Para pelaku UMKM diharapkan mampu mengenal berbagai jenis media sosial selain itu para pelau UMKM dapat memilih dan mengoptimalkan media sosial yang telah dipilih. Hal ini akan mendukung kelancaran menggunakan media sosial dan terfokus hanya beberapa media sosial saja. Dengan pengenalan ini akan menambah wawasan para pelaku usaha guna melakuakan promosi melalaui media sosial.

2. Pelatihan desain pemasaran

Perlu adanya pelatihan desain seperti ini diharapkan masyarakat mampu membuat selebaran promosi yang dapat menarik minat konsumen sehingga produk mereka akan terjual. Aplikasi yang digunakan untuk mendesain adalah Canva. Aplikasi ini sanagat cocok karena mudah diopersikan juga gratis dapat di download di smartphone masing masing. Dalam aplikasi juga tersedia templat dan tema sehingga pelaku usaha dapat memilih sesuai selera atau tema sesusi produk masinhg masing. Jika kemasan produk baik maka konsumen tidak ragu untuk membeli produk ini.

3. Pembuatan media sosial dan pendampingan

Setelah selebaran jadi maka perlu adanya pembuatan akun media sosial yang digunakan adalah Facebook dan Instagram. Kedua aplikasi ini umum digunakan oleh masyarakat. Selain itu pengoprasian media sosial ini juga sangat mudah. Setelah itu perlu adanya pendampingan secara berkala agar para pelaku usaha dapat mengoptimalkan media sosial dan bisa berlangsung secara lama.

\section{HASIL DAN PEMBAHASAN}

Kegiatan pengabdian masayarakat ini dilakukan dalam sehari dengan peserta ibu ibu pelaku UMKM. Pertemuan ini dilaksanakan selama 1 setengah jam. Seluruh peserta membawa alat komunikasi berupa smartphone serta sudah mempunyai email pribadi yang terdaftar di smartphone. Pertemuan ini dilaksana di kantor desa Gunungsari dan dihadiri oleh ibu rumah tangga yang mempunyai pekerjaan sampingan pelaku usaha berjumlah 7 orang. 


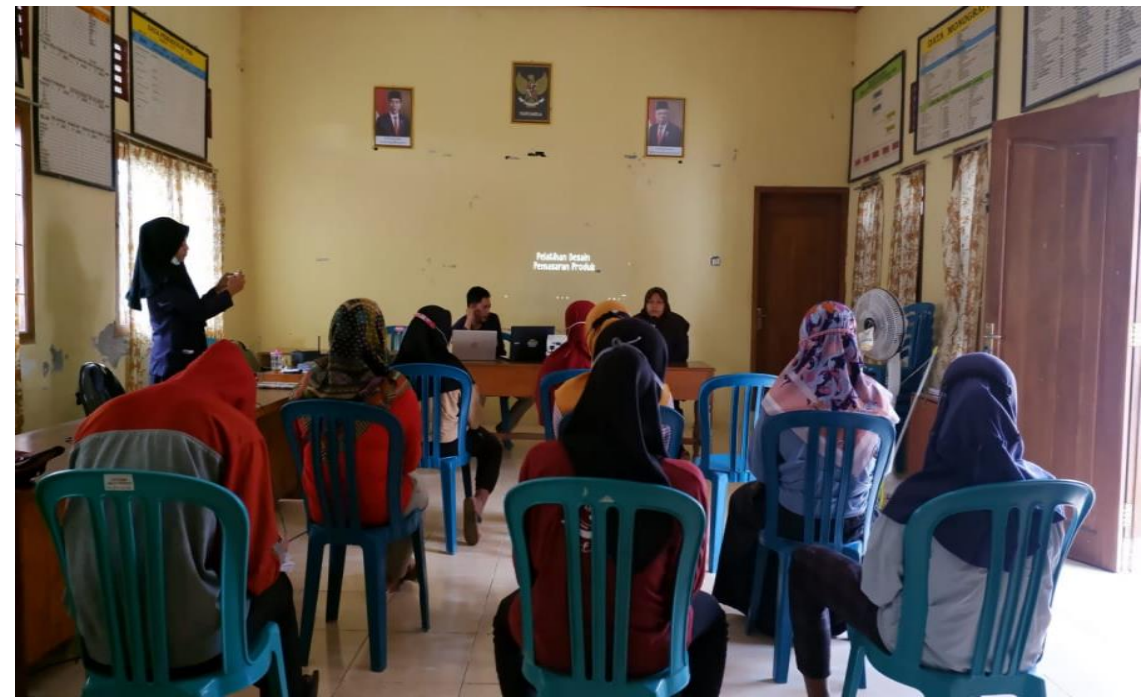

Gambar 3. Proses sosialisasi pemasaran melalaui media sosial

Dalam pertemuan ini, pemahaman dari peserta mengenai media sosial masih dirasa kurang dan belum mengenal media sosial secara mendalam. Peserta hanya mengenal media sosial untuk kebutuhan komunikasi dan mencari hiburan dengan menonton video. Hal ini cukup untuk menjadi dasar pengenalan media sosial sebagai media pemasaran. Dalam tahap awal para peserta masih belum mempunyai gambaran luas mengenai pemasaran melalu media sosial. Kemudian untuk memberikan gambaran maka perlu diberikan contoh media sosial yang sudah digunakan untuk media promosi. Pemberian contoh penggunan media facebook dan instagram. Dalam media facebook cara pemasaran dapat menggunakan akun pribadi kemudian di pasarkan melalui grup facebook atau melalaui market place. Dalam instgram dapat melalui fitur instagram bussines.

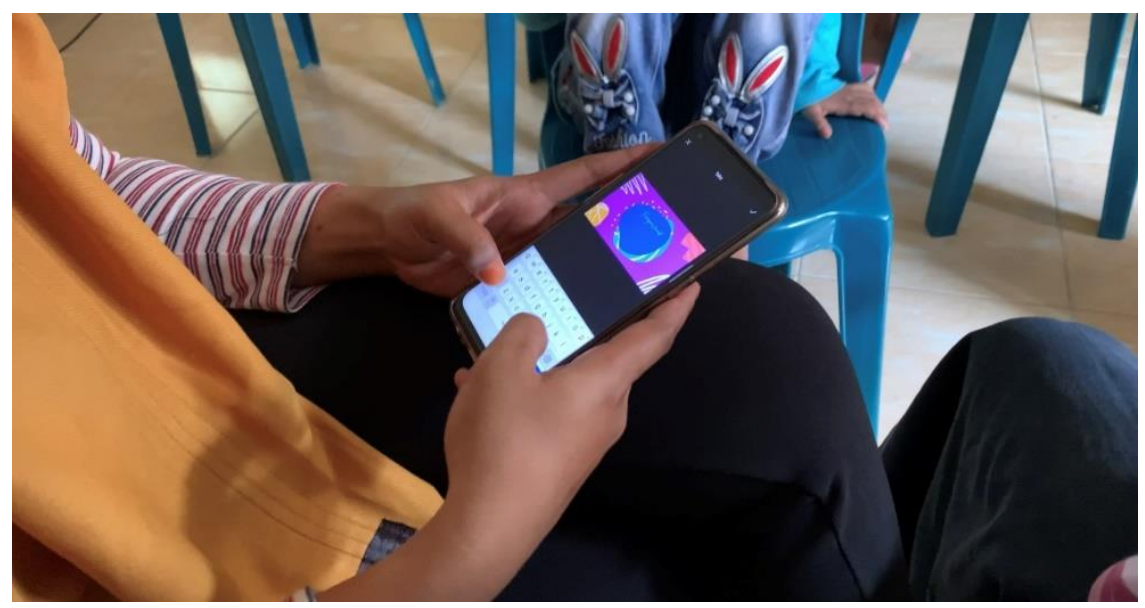

Gambar 4. Pelatihan desain pemasaran

Setelah dirasa sudah cukup menegerti kemudian lanjut ke tahap pelatihan desain pemasaran. Peserta mencari ide usaha yang akan dikembangkan atau pengembangan usaha yang sudah ada. Dalam tahap ini peserta banyak yang belum bisa menggunakan aplikasi maka perlu adanya bimbingan dan arahan agar bisa menggunakan aplikasi dengan baik. Dalam pelatihan ini aplikasi yang digunakan adalah Canva. Aplikasi ini dapat didownload denagn mudah melalui smartphone peserta selain itu aplikasi ini juga gratis, dan tersedianya banyak templat sehingga memudahkan para 
peserta untuk membuat selebaran. Proses ini berjalan cukup lama karena tingkat kesulitan dan tidak bisa sempurna secara instan.

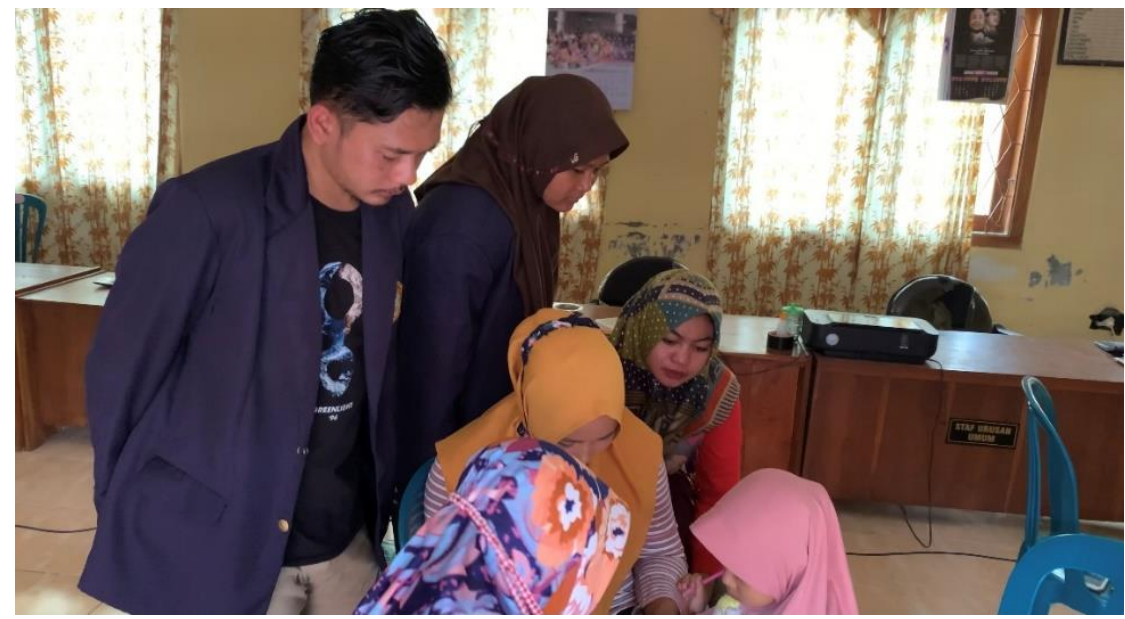

Gambar 5. Pembuatan media sosial dan pendampingan

Setelah dirasa cukup dan bisa maka dilanjutkan ke tahap terakhir yaitu pembuatan media sosial Facebook dan Instagram. Sebagian besar peserta sudah memiliki akun Facebook maka perlu mendaftar akun Instagram. Setelah memiliki akun media sosial peserta mengunggah bahan yang sudah di buat tadi. Sambil berjalan peserta juga diberikan bagaimana membuat caption yang dapat mendatangkan minat pembeli, serta menggenalkan fasilitas media sosial Instagram seperti hastag, follower, instagram bussines dan pengenalanan fasilitas facebook yaitu grup facebook, market place, halaman facebook. Pendamingan setelah dialakukannya pertemuan ini juga dilaksanan dengan harapan agar usaha yang sudah dijalankan berjalan dengan durasi yang lama.

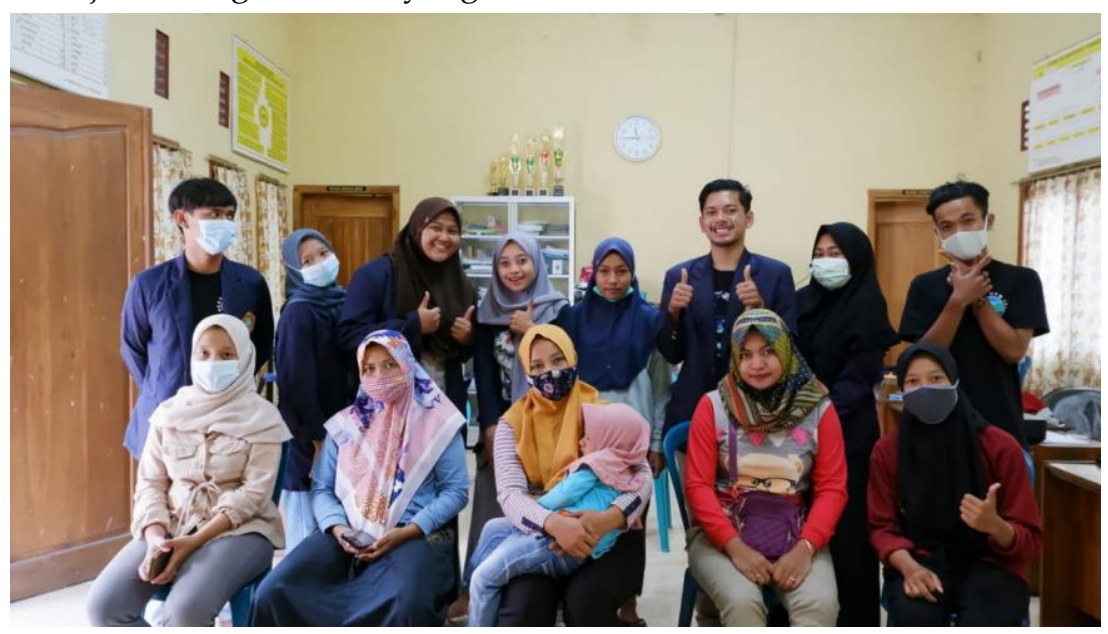

Gambar 6. Foto bersama peserta

\section{KESIMPULAN}

Teknologi dan Informasi berupa media sosial dapat menjadi media untuk pemasaran UMKM di masa New Normal. Memberikan kemudahan bagi para pelaku usaha karena tidak perlu melakuakan peamasaran produk secara tradisional lagi produk yang sudah dipasarkan sudah dapat dijangkau oleh masayarkat luas. Selain itu dengan pemasaran melalui media sosial juga menurnukan inntensitas untuk bertemu dengan banyak orang. Hanya dengan jari barang bisa samapai ke tempat tujuan. 


\section{DAFTAR PUSTAKA}

Abidin Achmad, Z., Zendo Azhari, T., Naufal Esfandiar, W., Nuryaningrum, N., Farah Dhilah Syifana, A., \& Cahyaningrum, I. (2020). Pemanfaatan Media Sosial dalam Pemasaran Produk UMKM di Kelurahan Sidokumpul, Kabupaten Gresik. Jurnal Ilmu Komunikasi, 10(1), 17-31. https://doi.org/10.15642/jik.2020.10.1.17-31

Anita, Muharmi, Y., \& Tria Siska, S. (2018). Penentuan Tingkat Minat Belanja Online Melalui Media Sosial Menggunakan Metode Clustering K-Means Anita,. Biomass Chem Eng, 3(2), ثقنثقن. Retrieved from http://journal.stainkudus.ac.id/index.php/equilibrium/article/view/1268/1127\%0Ahttp://publicacoes.cardiol.br/p ortal/ijcs/portugues/2018/v3103/pdf/3103009.pdf\%0Ahttp://www.scielo.org.co/scielo.php?script=sci_arttext\&pid= S0121-75772018000200067\&lng=en\&tlng=en

Dwi Riyanto, A., \& Noeris, M. F. (2018). Pelatihan Pemanfaatan Media Sosial Sebagai Media Promosi Online Untuk Pelaku UMKM di Cilacap, 2(2), 53-58.

Harahap, D. A. (2018). Perilaku Belanja Online Di Indonesia: Studi Kasus. JRMSI - Jurnal Riset Manajemen Sains Indonesia, 9(2), 193-213. https://doi.org/10.21009/jrmsi.009.2.02

Hariyanti, N. T., \& Wirapraja, A. (2018). Pengaruh Influencer Marketing Sebagai Strategi Pemasaran Digital Era Moderen (Sebuah Studi Literatur). Jurnal Eksekutif, 15(1), 133-146.

Khairani, Z., Soviyant, E., \& Aznuriyandi, A. (2018). Efektivitas Promosi Melalui Instagram Pada Umkm Sektor Makanan Dan Minuman Di Kota Pekanbaru. Jurnal Benefita, 3(2), 239. https://doi.org/10.22216/jbe.v3i2.2738

Mansir, F. dan H. P. (2021). Pemberdayaan Masyarakat Melalui Digital Marketing dan Media Sosial Sebagai Media Promosi Era Pandemi Covid -19 di UMKM Panggungharjo Sewon Bantul. Abdimas Singkeru, 1(1), 39-50.

Muzdalifah, L., Novie, M., \& Zaqiyah, S. (2020). Pemberdayaan Pelaku UMKM Menuju UMKM Go-Digital di Era Pandemi Covid 19 dan Era New Normal Bagi Pelaku UMKM Sidoarjo. Seminar Nasional Sistem ..., 2200-2208. Retrieved from https://www.jurnalfti.unmer.ac.id/index.php/senasif/article/view/296

Permana, S. D. H., \& Cendana, M. (2019a). Pemanfaatan Media Sosial Sebagai Strategi Promosi bagi kelangsungan UMKM. Journal Community Development and Society, 1(June), 1-10.

Permana, S. D. H., \& Cendana, M. (2019b). Pemanfaatan Sosial Media sebagai Strategi Promosi bagi Sustainability Bisnis UMKM. ETHOS (Jurnal Penelitian Dan Pengabdian), 7(2), 163-169. https://doi.org/10.29313/ethos.v7i2.4382

Priambada, S. (2015). Manfaat Penggunaan Media Sosial Pada Usaha Kecil Menengah (Ukm). Seminar Nasional Sistem Informasi Indonesia, (November), $2-3$.

Purwidiantoro, M. H., Kristanto, D. F., \& Hadi, W. (2016). Pengaruh Penggunaan Media Sosial Terhadap Usaha Kecil Menengah (UKM). AMIK Cipta Darma Surakarta, 1(1), 30-39. Retrieved from http://journal.amikomsolo.ac.id/index.php/ekacida/article/view/19/11

Rulandari, N., Rahmawati, N. F., \& Nurbaiti, D. (2020). Strategi Komunikasi Pemasaran Usaha Mikro Kecil Dan Menengah Pada Era New Normal, 7(2), 39-42.

Sembiring, E. B., Neta, F., Nashrullah, M., Wirawan, A., \& Lumombo, L. (2019). Pemberdayaan Masyarakat Kampung Rempang Cate Melalui Pelatihan Pemasaran Digital untuk Produk Unggulan Pasir Panjang. JURNAL PENGABDIAN KEPADA MASYARAKAT (AbdiMas), 1(2), 104-117. https://doi.org/10.30871/abdimas.v1i2.1147

Untari, D., \& Fajariana, D. E. (2018). Strategi Pemasaran Melalui Media Sosial Instagram (Studi Deskriptif Pada Akun @Subur_Batik). Widya Cipta, 2(2), 271-278. Retrieved from http://ejournal.bsi.ac.id/ejurnal/index.php/widyacipta

Utomo, S. H., Qurrata, V. A., Purnamasari, V., Seprillina, L., Malang, U. N., Pembangunan, E., ... Penjualan, O. (2019). Peningkatan Omset Penjualan Melalui Media Sosial Pada Usaha Kecil Menengah Alas Kaki Berbahan Kulit. Jurnal Karinov, 2(1), 1-5. Retrieved from http://journal2.um.ac.id/index.php/jki/article/view/8267/3932 